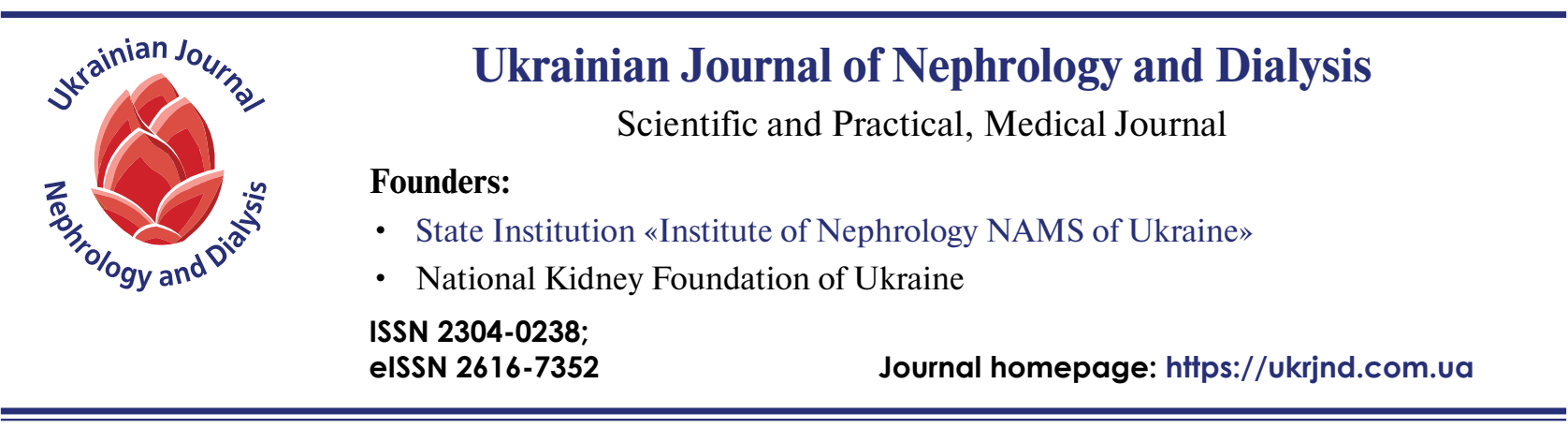

\section{Nephrology School}

doi: 10.31450/ukrjnd.4(60).2018.07

\section{Kolesnyk}

The unanswered questions in hyperuricemia: is it a cause of chronic kidney disease, a compensation mechanism, a coincidence, a consequence of disease or concurrent phenomenon?

SI «Institute of Nephrology of the National Academy of Medical Sciences»

\section{Citation:}

Article history:

Received 26 October 2018

Received in revised form 08 November 2018

Accepted 22 November 2018
Kolesnyk M. The unanswered Questions in Hyperuricemia: is it a cause of chronic kidney disease, a compensation mechanism, a coincidence, a consequence of disease or concurrent phenomenon? Ukr J Nephr Dial. 2018;4(60):48-61. doi: 10.31450/ukrjnd.4(60).2018.07

\begin{abstract}
Chronic kidney disease (CKD) has become a global public health problem because of its high prevalence and the accompanying increase in the risk of end-stage renal disease, cardiovascular disease, and premature death. The role of uric acid (UA) in the pathogenesis and progression of CKD remains controversial. Although many evidence-based studies have suggested that UA itself may harm patients with CKD by increasing inflammation and CKD progression, the issue is still a matter of discussions. In this review we try to clarify what is hyperuricemia - cause of CKD, compensation, coincidence, consequence of CKD or it is only an epiphenomenon, and to evaluate current evidence of different types of targeted hypouricemic therapy effectiveness. So, to treat or not to treat?
\end{abstract}

Keywords: uric acid; hyperuricemia; renal insufficiency, chronic kidney disease; glomerular filtration rate; therapy

Conflict of interest statement: author declared no competing interest.

(c) M. Kolesnyk, 2018. All rights reserved.

Correspondence should be addressed to Mykola Kolesnyk: director@inephrology.kiev.ua 


\title{
М.О. Колесник
}

\section{Гіперурикемія - причина хронічної хвороби нирок, компенсаторний механізм, випадковість, наслідок чи паралельно існуючий феномен?}

\author{
ДУ «Інститут нефрології Національної академії медичних наук України»
}

Резюме. Хронічна хвороба нирок (ХХН) стала глобальною медико-санітарною проблемою, що обумовлено ї̈ значною розповсюдженістю, високим ризиком формування термінальної стадії, високою частотою кардіоваскулярних ускладнень, передчасною смертю. Значення сечової кислоти (СК) для патогенезу та прогресування ХХН залишається контроверсійним. Хоча багато досліджень, виконаних відповідно до вимог доказової медицини, продемонстрували шкідливість гіперурикемії як такої для хворих на ХХН через індукцію запалення та прискорення ї̈ прогресування, ці питання все ще залишаються дискусійними.

У цьому огляді ми спробували визначити місце гіперурикемії: причина ХХН, компенсаторний механізм, випадковість, наслідки ХХН чи паралельно існуючий феномен і оцінити існуючі підходи до корекції гіперурикемії; лікувати чи не лікувати?

Ключові слова: сечова кислота, гіперурикемія, хронічна хвороба нирок (ХХН), термінальна стадія ХХН, швидкість клубочкої фільтрації.

Uric acid (UA) is the end product of purine nucleotides metabolic breakdown [1]. Xanthine oxidase (XO) which is a form of xanthine oxidoreductase, catalyzes the final oxidation of hypoxanthine and xanthine to UA. The kidneys eliminate approximately $70 \%$ of the UA load while $30 \%$ is eliminated by the gastrointestinal tract. UA is filtered by the glomeruli and the amount of UA excretion depends on its reabsorption and secretion mainly at the proximal tubule. Above $5-10 \%$ of the filtered UA is excreted with urine, while $90 \%$ is reabsorbed.

Hyperuricemia is defined as a serum UA level $>$ $416 \mu \mathrm{mol} / \mathrm{L}$ in males and $>357 \mu \mathrm{mol} / \mathrm{L}$ in females [1]. There are several ways to define UA: (i) a statistical definition that defines high uric acid (HUA) as serum (S) UA lying more than 2 standard deviations above the mean $(>458 \mu \mathrm{mol} / \mathrm{L}$ in men or $>393 \mu \mathrm{mol} / \mathrm{L}$ in women $)$ [2]; (ii) a physicochemical definition of HUA, taking into account the saturation point for monosodium urate crystals ( $\geq 357 \mathrm{mcmol} / \mathrm{l}$ ) [3]; (iii) a risk definition based UA values associated with an increased cardiovascular risk ( 476 or $535 \mathrm{mcmol} / 1$ as the limit to begin treatment) [4] or (iv) a risk for kidney function definition based on upper limited expected SUA values according to serum creatinine $(\mathrm{SCr}<0,132 \mu \mathrm{mol} / \mathrm{L}: \mathrm{SUA}>535 \mu \mathrm{mol} / \mathrm{L}$, $\mathrm{SCr} 0,132-0.176 \mu \mathrm{mol} / \mathrm{L}: \mathrm{SUA}>595 \mu \mathrm{mol} / \mathrm{L}$, and $\mathrm{SCr}$ $>0.176 \mu \mathrm{mol} / \mathrm{L}$ : SUA $>714 \mathrm{mg} / \mathrm{dL}$ [5]).

Hyperuricemia is the result of the balance between UA production and excretion. In more than $90 \%$ of the cases, HUA is due to impaired renal excretion of UA [6]. Asian patients with end-stage renal disease (ESRD)

$$
\begin{gathered}
\text { Mykola Kolesnyk } \\
\text { director@inephrology.kiev.ua }
\end{gathered}
$$

present higher rates of HUA, and men have a higher risk of HUA and gout in the general population [7]. Data from several studies have associated HUA with increased incidence and/or progression of CKD $[2,4$, 7-17].

It has been demonstrated that the prevalence of HUA rises in parallel with the glomerular filration rate (GFR) decline, which is present in $40 \%$ to $60 \%$ of patients with CKD stages I to III and $70 \%$ of patients with CKD stage IV or stage V [6].

There is no doubt about a strong relationship between HUA and CKD, but the details of this relationship are still controversial. In more than $66 \%$ of cases patients with predominantly nondiabetic stages 3-4 $\mathrm{CKD}$, had UA>416 $\mu \mathrm{mol} / \mathrm{L}$ [8]. In the last two decades, HUA was accepted as a risk factor for incident or progressive CKD, but the causality remained uncertain. Wang Y. et al. [18] performed a meta-analysis based on 11 papers with a total of 753 participants and reported that UA-lowering therapy is associated with a significant reduction in the serum creatinine concentration and an increase in the estimated GFR, HUA, oxidative stress, and inflammation.

It was believed that urate nephropathy does not exist [6] and HUA was considered to cause merely UA nephrolithiasis or acute UA nephropathy in the tumor lysis syndrome [6]. However, this historical belief was based on the incorrect assumption, that the mechanism of kidney damage should be mediated obligatorily by precipitation of monosodium urate crystals, similar to the pathogenesis of gout $[\mathbf{1 9}, \mathbf{2 0}]$.

Uric acid in CKD pathogenesis. Recent epidemiological data in humans and experimental animal model of HUA, have provided evidence of direct involvement of soluble SUA in the pathogenesis of CKD. UA crystals have the capacity to adhere to the surface of renal epithelial cells [21] and induce an acute inflammatory response in such cell lines [6] In addition to an increased 
risk of kidney stone formation, such effects have been shown to reduce the GFR [6]. The human urate transporter, i.e. URAT1 (encoded by the SLC22A12 gene), facilitates UA reabsorption in the proximal convoluted tubule A recent study showed that GLUT9 (encoded by SLC2A9) - member of the glucose transporter family, could be a major regulator of UA homeostasis. UA activates the cytoplasmic phospholipase A2 and inflammatory transcription factor nuclear factor $-\kappa \mathrm{B}(\mathrm{NF}-\kappa \mathrm{B})$, leading to the inhibition of proximal tubular cellular proliferation in vitro. Increasing serum UA levels leads to systemic cytokine production, i.e. tumor necrosis factor $\alpha$ and the local expression of chemokines, monocyte chemotactic protein 1 in the kidney and cyclooxygenase 2 (COX-2) in blood vessels. The withdrawal of UA-lowering therapy was found to increase urinary transforming growth factor- $\beta 1$ in a group of HUA patients with CKD $[6,22]$.

Several studies provided evidence that UA mediates endothelial dysfunction contributing to CKD and cardiovascular disease (CVD) progression. Endothelial dysfunction with HUA in the early stages of CKD is associated with micro-inflammation and oxidative stress [18, 23, 24]. Increasing UA levels could induce oxidative stress and endothelial dysfunction, resulting in the development of both systemic and glomerular hypertension in association with elevated renal vascular resistance and reduced renal blood flow [18]. Findings from animal studies supported that UA itself may promote endothelial dysfunction by inhibition of nitric oxide function. [25] On the other hand, UA may have a protective role under certain conditions. Recently, Johnson et al. [10] reported that on one hand UA is a pro-oxidant in the intracellular environment by stimulating NADPH oxidases, while outside the cell is a potent antioxidant. On the other hand, it could be hypothesized that XO activity and not UA itself plays a crucial role on oxistress, but all these hypotheses remain to be proven [10].

Hypertension is also commonly associated with renal vasoconstriction, which also leads to UA retention [26]. Both CKD and CVD are characterized by lowgrade inflammation. Inflammation may be considered as a potential underlying mechanism linking HUA, CKD, and CVD. In vascular smooth muscle cells, UA promotes inflammation by activating $\mathrm{NF}-\kappa \mathrm{B}$ and by enhancing serum $\mathrm{C}$-reactive protein (CRP) expression. Interestingly, $C$ reactive protein $(\mathrm{CRP})$ in combination with HUA may interact on the development of albuminuria and concomitant CKD progression on type 2 diabetic patients [27]. A significant positive correlation between CRP and serum UA levels was observed in 337 CKD patients. In this regard, it could be assumed that HUA is a marker of inflammation associated with both CKD and CVD [27].

Risk factors for CKD progression associated with HUA are shown in Table 1.

Risk factors for CKD progression associated with HUA [2]

Table 1

\begin{tabular}{|c|}
\hline Diabetes \\
\hline Metabolic syndrome \\
\hline Hypertension \\
\hline Oxidative stress \\
\hline Inflammation \\
\hline Endothelial dysfunction \\
\hline CsA nephrotoxicity \\
\hline
\end{tabular}

Relationship of HUA - chronic kidney disease incidence and progression. In one study, HUA rose to $58 \%$ among the patients receiving antihypertensive therapy, particularly in those receiving diuretics [6]. High plasma UA levels are common in patients with arterial hypertension [28, 29]. Elevated serum UA levels decrease the renal blood flow and the GFR and strongly associated with endothelial dysfunction $[10,18,30]$.

Several epidemiological studies in the general population and in patients with CKD show that UA is a major independent risk factor for the development and progression of renal disease $[8,31]$. This association was seen in studies with patients with diabetes mellitus as well $[8,31]$. In the recent meta-analysis involving
13 observational trials with more than 190,000 patients with normal renal function, the presence of HUA was an independent predictor for the development of CKD. In HUA the risk for new-onset CKD was twofold increased and this effect was seen with comparable magnitude in both patients with and without diabetes [16, 31]. This study which retrospectively assessed the longitudinal association between UA level and CKD progression in a Chinese population showed a higher UA level is associated with a significant rapid decline in eGFR and a higher risk of kidney failure, particularly in patients without proteinuria. These findings suggest HUA is a potential modifiable factor of CKD progression. Nevertheless, some studies have reported HUA 
to predict progression in established CKD, especially patients with IgA nephropathy $[\mathbf{1 4}, \mathbf{3 2}]$. In a retrospective cohort of patients with IgA nephropathy $(n=353)$, HUA was a significant independent risk factor for the doubling of serum creatinine or progression to ESRD over a mean follow-up of 5 years $[14,32]$. In another retrospective cohort of 803 patients with CKD, HUA (>6 mg/dl) was significantly associated with progression to ESRD [14, 32].

On the contrary, this positive association between HUA and CKD progression has not been supported by other studies. In the Mild to Moderate Kidney Disease study, patients with non-diabetic CKD $(n=177)$ were followed for a 7-year period and HUA (after adjustment for GFR and proteinuria at baseline) was not an independent predictor of CKD progression [14]. Similarly, in the Modification of Diet in Renal Disease study 838 patients with CKD stage 3-4 were followed for 10 years and again HUA was not significantly associated with the development of end stage renal disease (ESRD) [5].

A cohort study including 840 participants with CKD stages 3 and 4 reported that HUA was not an independent risk factor for CKD progression, but was correlated with increased risk for all-cause mortality and CV mortality. In accordance, a prospective 7 years follow-up study including 227 Caucasian patients with non-diabetic CKD, revealed that HUA did not predict CKD progression [33]. These contradictory results may be explained by the differences in the case mix and the follow-up period as well as gender differences (higher incidence of HUA in men), and different thresholds of HUA in these studies. Thus, some authorities support that UA is not a real risk factor for CKD. In addition, given the decreased clearance of UA, even in the early stages of CKD, HUA might be seen as an epiphenomenon and not a real cause of CKD. In this respect, HUA may just reflect the severity of CKD (advanced stage). An explanation for this contradiction may lay on the specific pathomechanism. UA leads to renal damage primarily by causing systemic and glomerular hypertension [8]. In patients with renal disease, who commonly develop severe systemic hypertension mainly due to water and sodium retention, the contribution of the UA dependent pathomechanism may become less relevant.

In CKD the prevalence of HUA, gout and UA lithiasis is increased because the kidneys are the primary excretion root for UA [5]. Epidemiological findings implicate an additional connection of HUA with the development and progression of CKD, however, a respective treatment strategy has not been adopted yet. On the contrary, indications for treatment of HUA in CKD patients are limited to a prophylaxis of gout and lithiasis. In this context, several studies have been conducted, to investigate the impact of UA lowering treatment on renal outcomes $[\mathbf{1 4}, \mathbf{1 9}, \mathbf{3 4}]$. These were all single center trials, which had only small number of participants and a limited duration of follow up and most of them were studying allopurinol $[5,34]$.
Gouty nephropathy and CKD. In 1960, Talbott and Terplan found that nearly all subjects with gout had arteriosclerosis, glomerulosclerosis and interstitial fibrosis in their kidneys. As many of these subjects also had urate crystals in their tubules and interstitium, the disease was termed "gouty nephropathy" [35]. But urate crystal deposition in the kidneys was also found in patients without renal disease. The diffuse renal scarring and the coexistent conditions of hypertension and vascular disease in many of the autopsy subjects led some to suggest that the renal injury in gout was secondary to these latter conditions rather than to HUA [35]. In the tubular cells, UA was found to induce epithelial to mesenchymal transition, which had been widely accepted as a key contributor to the development of renal fibrosis in CKD [35].

UA crystals adhere to the surface of renal epithelial cells and may induce an acute local inflammatory response. Some investigators suggested that the histological findings revealed in renal biopsy specimens in patients with HUA such as tubulointerstitial fibrosis, arteriosclerosis, and glomerulosclerosis were similar with those observed in hypertensive renal disease. [2] These non-specific alterations were also present in advanced age or in patients with asymptomatic HUA. Additionally, gout is correlated with several other risk factors - diabetes, advanced age, and male sex. Thus, it is difficult to dissect the causal effect of UA from the synergic effect of the other risk factors. Therefore, the term gouty nephropathy has been considered as a mistake and, in the past, it was removed from the list of causes of CKD in the classical nephrology textbooks [2].

Hyperuricemia, diabetes, and diabetic nephropathy. Diabetic nephropathy is one of the leading causes of ESRD. HUA promotes insulin resistance and concomitant hyperinsulinemia. Diabetes is one of the leading causes of CKD, and HUA has been associated with the pathogenesis of the microvascular complications of diabetes [36]. Data from clinical studies supported the concept that HUA is a risk factor for diabetic nephropathy. Bellomo G. [3], Sowers J.R. [37], Zhang et al. [22] reported that HUA increases oxidative stress and inhibits the function of pancreatic cells. Kidney tubular function is influenced by insulin metabolic signaling and renal UA clearance decreases with reducing insulin-mediated glucose disposal.

In subjects with type 1 diabetes, an elevated serum $\mathrm{UA}$, even when within the normal range, is a strong predictor for the development of CKD [38]; UA also predicts the development and progression of CKD in subjects with type 2 diabetes an elevated serum UA level has been associated with intrarenal arteriolar lesions [19], consistent with the vascular effects observed in laboratory animals with HUA. Concretely, a renal biopsy study in Japanese patients with CKD (eGFR $<60 \mathrm{~mL} /$ $\min / 1,73 \mathrm{~m}^{2}$ ) found that increased serum UA levels $(>428 \mu \mathrm{mol} / \mathrm{L})$ were independently associated with histological evidence of renal arteriolosclerosis, characterized by arterial wall thickening and hyalinosis [30] 
Jalal D.I. et al. [30] reported that baseline elevated UA levels predicted persistent macro-albuminuria in patients with type 1 diabetes. In accordance, findings from the Coronary Artery Calcification in Type 1 Diabetes Study supported that high serum UA levels predict the development of albuminuria [30]. The authors reported that every $60 \mu \mathrm{mol} / \mathrm{L}$ increase in serum UA levels may lead to an $80 \%$ increased risk for micro- or macroalbuminuria. Jalal D.I. et al. [30] have found an association between serum UA levels and early GFR loss in 355 participants with type 1 diabetes. In an observational, cross sectional study, high UA serum levels were associated with a decline in GFR in type 1 diabetic patients with normo- or microalbuminuria. Similar, serum UA levels were correlated with micro and macrovascular complications in type 2 diabetic patients [21]. Data from another study, including 1449 type 2 diabetic patients with preserved kidney function and a 5 years follow-up period, reported that the presence of HUA doubled the risk of incident CKD. The authors concluded that HUA is an independent risk factor for the development of CKD in type 2 diabetic patient [17]. Kim W. J. et al [11] reported that increased levels of UA may predict the occurrence of advanced CKD in 512 type 2 diabetics with preserved renal function. reported that HUA in type 2 diabetes correlated with early onset or increased progression of diabetic nephropathy, whereas the opposite occurs with hypouricemia. In Japanese clinical trial including 1213 type 2 diabetic patients a positive independent association among HUA, coronary heart disease, and renal dysfunction was reported, supporting the hypothesis that HUA is implicated in the pathogenesis of the micro- and macro-vascular diabetic complications [39]. Ito $H$. et al. [39] had reported that HUA correlated with increased risk of macrovascular disease in diabetic CKD patients.

The impact of lowering UA on the progression of diabetic nephropathy is challenging, but few studies have been conducted in this field. According to RENAAL study, an angiotensin II antagonist losartan not only lowered blood pressure and proteinuria but also had UA lowering effect suggesting that the renoprotective effect of losartan may be partially attributed to decreased serum UA levels [40]. Moreover, the renoprotective effect of losartan was decreased from $22 \%$ to $17 \%$ after adjusting for the effect of allopurinol on serum UA levels, suggesting that UA may partially contribute to diabetic nephropathy progression [42].

Hyperuricemia, hypertension and CKD. Several studies reported that HUA predicts a higher risk of hypertension independently of other risk factors. Interestingly, HUA is associated even with prehypertension, especially when microalbuminuria is present. Hyperuricemia is not usually associated with secondary hypertension, disabling the hypothesis that HUA is an epiphenomenon of hypertension. Interestingly, HUA is not only associated with hypertension but also with its complications including left ventricular hypertrophy $[29,41]$.

Findings from several studies provided a direct evidence that UA is implicated in the pathogenesis of hypertension [26]. Microvascular changes caused by UA remain after correction of blood pressure indicating that UA contributes to microvascular disease independently of hypertension. Sheikhbahaei S. et al. [42] reported a synergistic effect between UA and various components of metabolic syndrome including hypertension and diabetes, on risk of CKD. Data from a recent prospective cohort study involving 2601 individuals reported that increased serum UA levels were independently associated with a faster decline of GFR and incident CKD and this association was stronger in hypertensive individuals. The authors concluded that hypertension mediates the correlation between high serum UA levels and CKD [43, 44, 45]. However, Gois P.H. et al. [46] reported that there is insufficient evidence of an antihypertensive effect of allopurinol.

Thus, the majority of patients with hypertension and HUA should present CKD, but actually this does not occur. Probably, UA in some instance mediates and contributes to CKD development and progression through hypertension-induced renal injury suggesting an indirect action on the pathogenesis of kidney disease. Another hypothesis is that CKD results in HUA, which, in turn, through hypertension-induced changes and endothelial dysfunction, aggravates the decline in renal function. Nevertheless, all these theories remain to be proven.

Several studies reported a beneficial effect of UA lowering on CKD progression and UA has been proposed as a promising target of therapy in CKD patients [18, 44, 47] (Table 2).

Table 2

\section{Randomized controlled trials lowering serum UA and its effect on renal function (cited from Ramirez M. R.G., Bargman J.M. [35] without changes)}

\begin{tabular}{|l|l|l|l|}
\hline \multicolumn{1}{|c|}{$\begin{array}{c}\text { Study (Primary } \\
\text { author and year) }\end{array}$} & \multicolumn{1}{|c|}{ Population } & \multicolumn{1}{c|}{ Intervention } & \multicolumn{1}{c|}{ Results } \\
\hline $\begin{array}{l}\text { Gibson et al. } \\
(1982) \text { [48] }\end{array}$ & 59 patients with primary gout & $\begin{array}{l}\text { Colchicine and allopurinol } \\
\text { versus colchicine alone }\end{array}$ & $\begin{array}{l}\text { Retarded an apparent decline of } \\
\text { renal function over 2 years }\end{array}$ \\
\hline $\begin{array}{l}\text { Chanard et al. } \\
(2003)[49]\end{array}$ & $\begin{array}{l}\text { 48 renal transplant patients } \\
\text { with hypertension, on } \\
\text { cyclosporine }\end{array}$ & Amlodipine or tertatolol & $\begin{array}{l}\text { Amlodipine decreased serum UA } \\
\text { levels and increased glomerular } \\
\text { filtration rate as compared with } \\
\text { tertatolol }\end{array}$ \\
\hline
\end{tabular}




\begin{tabular}{|c|c|c|c|}
\hline & & & Continuation of Table 2 \\
\hline $\begin{array}{c}\text { Study (Primary } \\
\text { author and year) }\end{array}$ & Population & Intervention & Results \\
\hline $\begin{array}{l}\text { Siu et al. (2006) } \\
\text { [50] }\end{array}$ & $\begin{array}{l}54 \text { hyperuricemic patients } \\
\text { with CKD }\end{array}$ & $\begin{array}{l}\text { Allopurinol versus standard } \\
\text { therapy }\end{array}$ & $\begin{array}{l}\text { Trend toward a lower serum } \\
\text { creatinine level in the treatment } \\
\text { group compared with controls } \\
\text { after } 12 \text { months of therapy. }\end{array}$ \\
\hline $\begin{array}{l}\text { Liu and Sheng } \\
\text { (2007) [51] }\end{array}$ & $\begin{array}{l}47 \text { hyperuricemic patients } \\
\text { with CKD }\end{array}$ & $\begin{array}{l}\text { Allopurinol versus standard } \\
\text { therapy }\end{array}$ & $\begin{array}{l}\text { Serum creatinine was lower } \\
\text { in the allopurinol group and } \\
\text { the rate of renal function } \\
\text { deterioration was significantly } \\
\text { decreased over } 12 \text { months }\end{array}$ \\
\hline $\begin{array}{l}\text { Kanbay et al. } \\
\text { (2007) [52] }\end{array}$ & 59 patients & $\begin{array}{l}\text { Allopurinol given to the } \\
\text { hyperuricemic patients and } \\
\text { no UA lowering therapy } \\
\text { for the normouricemic } \\
\text { patients }\end{array}$ & $\begin{array}{l}\text { Allopurinol therapy significantly } \\
\text { improved GFR but proteinuria } \\
\text { was unchanged }\end{array}$ \\
\hline $\begin{array}{l}\text { Malaguarnera et } \\
\text { al. (2009) [53] }\end{array}$ & 38 elderly patients with HUA & Rasburicase versus placebo & $\begin{array}{l}\text { Significant reduction in } \\
\text { creatinine and an increase } \\
\text { in creatinine clearance over } \\
2 \text { months }\end{array}$ \\
\hline $\begin{array}{l}\text { Goicoechea et al. } \\
\text { (2010) [34] }\end{array}$ & $\begin{array}{l}113 \text { patients with estimated } \\
\text { GFR }<60 \mathrm{~mL} / \mathrm{min}\end{array}$ & $\begin{array}{l}\text { Allopurinol versus standard } \\
\text { therapy (no UA lowering } \\
\text { therapy) }\end{array}$ & $\begin{array}{l}\text { Allopurinol treatment slowed } \\
\text { down renal disease progression } \\
\text { independent of age, gender, } \\
\text { diabetes, C-reactive protein, } \\
\text { albuminuria and renin- } \\
\text { angiotensin blocker use over } \\
24 \text { months }\end{array}$ \\
\hline $\begin{array}{l}\text { Momeni et al. } \\
\text { (2010) [54] }\end{array}$ & $\begin{array}{l}40 \text { patients with type } 2 \\
\text { diabetes mellitus and diabetic } \\
\text { nephropathy (proteinuria } \\
\text { of } 500 \mathrm{mg} / \text { day and serum } \\
\text { creatinine level }<3 \mathrm{mg} / \mathrm{dL} \text { ) }\end{array}$ & Allopurinol versus placebo & $\begin{array}{l}\text { Allopurinol reduced severity of } \\
\text { proteinuria after } 4 \text { months of } \\
\text { drug administration. No change } \\
\text { in creatinine was noted }\end{array}$ \\
\hline $\begin{array}{l}\text { Whelton et al. } \\
\text { (2011) [20] }\end{array}$ & $\begin{array}{l}116 \text { hyperuricemic patients } \\
\text { (post hoc) }\end{array}$ & $\begin{array}{l}\text { Febuxostat in } 40,80 \text { or } \\
120 \text { mg doses }\end{array}$ & $\begin{array}{l}\text { Improvement or maintenance } \\
\text { of estimated GFR was inversely } \\
\text { correlated with the quantitative } \\
\text { reduction in serum UA from } \\
\text { baseline over } 5 \text { years }\end{array}$ \\
\hline $\begin{array}{l}\text { Shi et al. (2012) } \\
\text { [14] }\end{array}$ & $\begin{array}{l}40 \text { hyperuricemic patients } \\
\text { with IgA nephropathy }\end{array}$ & $\begin{array}{l}\text { Allopurinol versus standard } \\
\text { therapy }\end{array}$ & $\begin{array}{l}\text { HUA predicted progression of } \\
\text { IgA nephropathy independently } \\
\text { of baseline estimated GFR over } \\
6 \text { months. No change in renal } \\
\text { progression or proteinuria was } \\
\text { noted }\end{array}$ \\
\hline $\begin{array}{l}\text { Pai et al. (2013) } \\
\text { [43] }\end{array}$ & $\begin{array}{l}183 \text { hyperuricemic patients } \\
\text { with CKD }\end{array}$ & $\begin{array}{l}\text { Allopurinol versus standard } \\
\text { therapy (no UA lowering } \\
\text { therapy) }\end{array}$ & $\begin{array}{l}\text { Allopurinol was associated with } \\
\text { decreased progression of renal } \\
\text { disease in CKD }\end{array}$ \\
\hline $\begin{array}{l}\text { Sircar et al. } \\
(2015) \text { [55] }\end{array}$ & $\begin{array}{l}93 \text { hyperuricemic patients } \\
\text { with CKD } 3 \text { and } 4\end{array}$ & Febuxostat versus placebo & $\begin{array}{l}\text { Febuxostat slowed the decline in } \\
\text { estimated GFR in CKD stages } 3 \\
\text { and } 4 \text { compared to placebo }\end{array}$ \\
\hline
\end{tabular}

Despite the small numbers, the trials have consistently shown that HUA is strongly associated with progression of renal disease and that treatment is beneficial in slowing this progression and that interrupting therapy may be deleterious.
Cyclosporine - the drug for immunosuppression post transplantation and to patients with autoimmune disease - is strongly associated with the development of HUA and gout [49]. The mechanism for Cyclosporine's strong association with HUA is unclear and may 
include an inhibitory effect on urate secretion [49]. Tacrolimus also commonly is used in transplantation immunosuppressive regimens and has been reported to increase serum urate levels in a manner similar to Cyclosporine [35]. However, data from the US Renal Data System in combination with Medicare claims data suggest that it may induce less clinical gout in kidney transplantation recipients (hazard ratio for Cyclosporine versus Tacrolimus: $1.24 ; 95 \%$ confidence interval: 1.06 to 1.45$)[35,49]$.

There is great controversy about the utility of treating asymptomatic HUA either to prevent or slow down the progression of CKD, given the conflicting results in several clinical studies [4].

Non-pharmacologic therapy (decreased alcohol consumption, dietary reduction in high purine foods, moderate increase in exercise) has been proven to be as effective as pharmacologic therapy. Lifestyle modifications in the treatment of HUA as well as use of well tolerated, easily accessible medication such as allopurinol will certainly not be too onerous to delay of renal disease progression [7]. These recommendations may be summarized as follows:

1 Exercise daily and reduce weight. Weight reduction through gradual caloric restriction and exercise can help lower SUA; nevertheless, the effect of this maneuver is modest (an average weight loss of $7.7 \mathrm{~kg}$ over 16 weeks decrease to a mean difference of $95 \mu \mathrm{mol} / \mathrm{L} \mathrm{SUA}$ in obese patients with gout) [4].

2 Limit consumption of purine-rich meat and seafood and consider omega- 3 fatty acid supplements with regard to the evidence about higher levels of meat and seafood consumption associated with HUA [14].

3 Limit high fructose corn syrup - sweetened soft drinks and energy drinks. Fructose increases SUA given the fact that once absorbed into the cell, unregulated phosphorylation of fructose by fructokinase leads to local ATP depletion and increased AMP production [57]. Hypercaloric supplementation with fructose $(+35 \%$ excess energy) at extreme doses (213-219 g/day) significantly increases SUA (mean difference $=30 \mu \mathrm{mol} / \mathrm{L}$ ). Even isocaloric exchange of fructose for other carbohydrates may be useful for hypertension treatment [57]; however, this maneuver does not affect SUA in participants from 21 trials [57].

4 The consumption of low-fat or nonfat dairy products reduced consumption of saturated fat, total fat, and cholesterol has a minimal effect in lowering SUA [4].

5 Subjects must limit their intake of beer, wine, and spirits [4]

Xanthine oxidase inhibitors such as allopurinol or febuxostat are the preferred agents to decrease UA levels due to their effectiveness in both overproducers and undersecretors of UA. Allopurinol is metabolized by $\mathrm{XO}$ to oxipurinol and both substrates act to inhibit XO [58]. Patients with CKD may be at an increased risk of toxicity with allopurinol because oxipurinol is cleared by the kidney [59]. It is widely recommended to start with low dosages of allopurinol in patients with CKD and slowly titrate it to an effective dose. In a small randomized trial by Siu Y.P. et al. [50], 54 HUA patients with mild to moderate CKD were assigned to allopurinol $(100-300 \mathrm{mg} / \mathrm{d}$ with the goal of normalizing serum UA levels) versus no therapy and followed up for 12 months. At the end of follow-up, a significantly larger number of participants in the control group achieved the combined end point of a serum creatinine level increase $\geq 40 \%$, dialysis, or death. More recently, a larger study conducted by Goicoechea et al. [34] included 113 HUA patients with CKD randomly assigned to the allopurinol group $(100 \mathrm{mg} / \mathrm{d})$ and the control group. At the end of the 2-year follow-up, the estimated GFR decreased in the control group and the GFR increased in the allopurinol group. A randomized double-blinded study by Feng et al. [60] showed that treating HUA in adolescents with newly diagnosed hypertension was effective at lowering the blood pressure. Similar to the studies mentioned, allopurinol was used to decrease serum UA levels and resulted in significant diminishment of both systolic and diastolic blood pressures compared with a placebo. Allopurinol therapy can be associated with fatal Stevens-Johnson syndrome, while screening for HLA-B68 may allow the elimination of subjects at highest risk for this condition [60]. Hypersensitivity syndrome occurs in $2 \%$ of patients and can be fatal. To minimize this complication, it is recommended to initiate allopurinol at a dose of $50-100 \mathrm{mg} /$ day in subjects with estimated GFR less than $30 \mathrm{~mL} / \mathrm{min} / 1.73 \mathrm{~m}^{2}$, increasing the dose to 200 or $300 \mathrm{mg} /$ day every $2-5$ weeks to achieve desired UA levels of $<6 \mathrm{mg} / \mathrm{dL}$; doses $>300$ $\mathrm{mg} /$ day are permitted so long as they are accompanied by appropriate patient education and monitoring for toxicity (e.g., pruritus, rash, elevated hepatic transaminases) [14]. Adherence to these published allopurinol dosing guidelines led to suboptimal control of HUA in most patients $[43,54]$. Results of two meta-analyses, which included most available randomized trials, were not conclusive. In the first, which involved 8 trials of patients with or without CKD at baseline [14] allopurinol therapy had no effect on eGFR but showed a reduction of serum creatinine levels in some studies [8]. In the second meta-analysis, which involved randomized trials with a total of 992 patients with CKD stage 3-5 [14, 34] treatment with allopurinol was associated with significant reductions in serum UA levels and a favorable influence on blood pressure and on eGFR compared with untreated controls [13]. Expectedly, both meta-analyses reported significant heterogeneity among these allopurinol trials in respect with design, end-points and follow-up period [61].

Data from a recent meta-analysis supported that allopurinol may delay progression of CKD [27]. However, in another meta-analysis including eight trials, an uncertain effect of allopurinol has been reported [62]. The effects of allopurinol on the progression of IgA nephropathy and diabetic nephropathy in type 1 diabetes mellitus $[63,64]$ are currently evaluated in two ongoing nationally sponsored trials. 
Febuxostat has been shown to be safe and effective for decreasing serum UA levels [55] and is suggested as alternative to allopurinol in HUA patients unable to tolerate the latter. In accordance, Sakai Y. et al. [58] reported that febuxostat by lowering UA levels in CKD patients may suppress the progression of CKD. Febuxostat does not appear to be associated with Stevens-Johnson-syndrome and its dosage does not need to be modified in CKD [59]. Febuxostat is metabolized mainly by the liver, has its elimination is primarily through renal and biliary routes, is effective and well tolerated in patients with mild CKD; yet the most commonly reported adverse drug reactions are liver function abnormalities, diarrhea, and rash [6]. For example, in the CONFIRMS trial with 2,269 subjects with gout, febuxostat $40 \mathrm{mg}$, febuxostat $80 \mathrm{mg}$, or allopurinol $300 \mathrm{mg}$ (200 mg in subjects with CKD3) reduced SUA less than $6 \mathrm{mg} / \mathrm{dL}$ in 45, 67, and $42 \%$ of patients respectively $[45,55,63,64]$. Recently, treatment with febuxostat was also evaluated in a randomized, double blind, placebo-controlled trial, which included 93 patients with asymptomatic HUA and CKD stage 3 and 4 . After 6 months, mean changes in eGFR were significantly more favourable in the febuxostat group compared with the placebo group [55]. Nevertheless, the FEATHER trial (Febuxostat versus placebo randomized controlled trial regarding reduced renal function in patients with HUA complicated by CKD stage 3) did not support this suggestion - compared to placebo, febuxostat did not mitigate the decline in kidney function among patients with stage 3 CKD and asymptomatic hyperuricemia (the study was just completed, article in press, https://www.ajkd.org/ article/S0272-6386(18)30834-5/fulltext). CKD FIX (Controlled trial of slowing of kidney disease progression from the inhibition of $\mathrm{XO}$ ) is currently ongoing in Australia.

Furthermore, topiroxostat, a XO inhibitor approved in Japan, was evaluated in a recent doubleblind trial of 123 patients with CKD stage 3 and HUA. This study showed that treatment with topiroxostat compared with placebo significantly reduced serum UA and the levels of albuminuria [63, 64]. The most commonly reported adverse drug reactions were liver function abnormalities, diarrhea, headache, nausea, and rash [34].

Other agents that can be used to decrease UA levels include uricosuric agents such as Probenecid and Benzbromarone. No large randomized trials regarding their effectiveness were performed.

One of the greatest advances in recent decades has been the advent of renal angiotensin aldosterone system (RAAS) blockade. With respect to UA metabolism, it is interesting to note is that not all RAAS blockade works in the same way. A review comparing the effect of angiotensin II receptor blockers (ARBs) on HUA showed that losartan was the only ARB that reduces serum UA levels [35]. A post hoc analysis of the trial on Reduction of Endpoints in Non-Insulin-
Dependent Diabetes mellitus with the Angiotensin II Antagonist Losartan (RENAAL) showed that the UA-lowering effect of losartan was associated with long-term renal risk reduction [35]. Losartan has the unique ability to lower serum UA levels by decreasing reabsorption, most probably by a direct URAT1 inhibition in the proximal tubule [40]. There is now evidence, that this aspect of losartan treatment may provide additional benefits for renal disease [40]. In a post hoc analysis of the RENAAL (Reduction of Endpoints in Non-Insulin-Dependent Diabetes Mellitus with the Angiotensin II Antagonist Losartan) trial, the risk of renal events (a doubling of serum creatinine or development of ESRD) was decreased by $6 \%$ for every $60 \mu \mathrm{mol} / \mathrm{L}$ decrement in serum UA levels during losartan treatment

Sodium glucose co-transporter 2 (SGLT2 encoded by SLC5A2) Inhibition of SGLT2 increases urinary glucose excretion, thereby improving glycemic control [65]. In addition, SGLT2 inhibitors reduce serum UA levels, possibly by indirect (via glucosuria) activation of the GLUT9 mediated urate transport [65]. Indeed, in the pooled analysis of data from four phase 3 placebo controlled trials the effect of canagliflozin, a SGLT2 inhibitor, was shown to reduce serum UA levels [66]. A recently published randomized placebo-controlled trial showed, that the SGLT2 inhibitor, empagliflozin slowed the progression of renal disease in patients with diabetes mellitus. Empagliflozin slowed the progression of renal disease and effectively reduced serum UA levels. The authors postulated a possible contribution of this latter effect on renal outcomes [66]. These beneficial effects of SGLT2 inhibition must be weighed against potential side effects [65]. Preliminary data suggest that SGLT2 inhibitors can reduce serum UA levels, which may in turn contribute to the renoprotective effect shown in diabetic nephropathy. Ongoing clinical studies are prospectively evaluating the effect of SLGT2 inhibitors on serum UA levels, renal outcomes and CKD. The CREDENCE trial, is a phase 3 study evaluating canagliflozin as secondary prophylaxis in patients with type 2 diabetes mellitus and nephropathy (CKD stage 2 or 3 and severe albuminuria). The trial will assess whether canagliflozin has renal and vascular protective effects. The ongoing phase 4 CANVAS-R trial will study the effects of canagliflozin on renal endpoints in adults with type 2 diabetes mellitus [35].

In conclusion, before a UA lowering therapy of any form can be embraced for prophylaxis of CKD, there is a need to establish its efficacy by large randomized controlled trials. Also safety issues are to be adequately addressed.

According to the Hemodialysis (HEMO) study, CV disease (CVD) is the leading cause of death in dialysis patients. Cheung A.K. [67] and there is a reciprocal relationship between CVD and CKD, and UA might be considered as a common dominator linking these two clinical conditions. 
Similar to the general population, the evidence for a strong correlation between UA and CVD mortality in CKD patients is controversial. Data from epidemiological studies in CKD patients revealed a direct linear or "J-shaped" correlation with all cause or CV mortality [51]. However, according to other studies, this correlation diminished after adjustment for GFR or proteinuria. Similar, Kanbay M. et al. [52] reported that HUA predicts CV events in advanced CKD stages. Liu W.C. et al. [51] suggested that HUA is a risk factor for all-cause and $\mathrm{CV}$ events but not for renal outcomes in stages 3-5 CKD patients. Additionally, HUA independently correlates with CV mortality and this correlation is stronger with decreasing GFR [38]. Chung W. et al. [1] revealed that HUA is an independent risk factor for all-cause mortality in CKD patients undergoing percutaneous coronary intervention but not in those without CKD. Allopurinol administration in hypertensive CKD patients prevents CV and all-cause mortality [28].

In the hemodialysis (HD) population, the data are more contradictory. Recently, Lee C.T. et al. [68] reported that serum UA levels were independently associated with valvular and vascular calcifications in 81 HD patients. Antunovic T. et al. [69] reported that HUA may predict all-cause and CV mortality in HD patients. Lobo J.C. et al. [70] reported a positive association of UA levels and several markers of inflammation suggesting a potential role of HUA in the pathogenesis of atherosclerosis in HD patients. On the contrary, data from a retrospective study reported that low serum UA concentration in HD patients with hypoalbuminemia is a mortality risk factor. Another large retrospective study involving 5827 HD patients reported that higher serum UA levels were correlated with lower risk of all-cause and CVD mortality [71].
These results could be explained by the reverse epidemiology - HUA may reflect a better nutritional status in HD patients and low UA levels may represent a form of protein energy wasting syndrome.

Contradictory results have been reported also in peritoneal dialysis (PD) patients. Data from two studies revealed an association of HUA with all-cause and CVD mortality $[60,72]$. However, in a recent observational study including 2264 PD patients, only a weak correlation of HUA with all-cause mortality could be detected [56]. The lack of large prospective studies in this field does not lead to reliable conclusions.

Discussion. Currently there is renewed interest in the relationship between UA and nephropathy, which has been considered to be a dead subject in the lasts decades [35]. New data in this field suggest that serum UA may be a risk factor for CKD. However, the influence of UA lowering therapies on renal outcomes is still largely unclear. Efficacy and safety of UA lowering therapies has to be further investigated and large randomized controlled trials have to be planned.

In respect to UA lowering treatment in CKD, there are still many unresolved points to address. Namely, the choice of the oxidase inhibitor with the right efficacy-safety profile in CKD, the role of UA reducing diet alterations, the limit of UA serum levels to be aimed at, the optimal medication dose. It is also unclear whether in subjects with CKD the combination with either ACE inhibitors or with ARBs abolishes the benefit of the UA lowering treatments. Finally, it is clear, that there are more questions than answers. The ongoing studies will probably add some more clarity to the field of UA lowering therapy in CKD [35].

Other drugs with beneficial effect on HUA are shown in Table 3.

Table 3

Uric acid-lowering drugs [15]

\begin{tabular}{|l|l|l|l|}
\hline \multicolumn{1}{|c|}{ Drug } & \multicolumn{1}{|c|}{ Mechanism } & \multicolumn{1}{c|}{ Evidence } & \multicolumn{1}{c|}{ Comment } \\
\hline Topiroxostat & Xanthine oxidase inhibitor & $\begin{array}{l}\text { Reduce 45 SUA and 33\% the } \\
\text { levels of albuminuria }\end{array}$ & $\begin{array}{l}\text { Profile similar to } \\
\text { febuxostat }\end{array}$ \\
\hline Benzbromarone & Uricosuric & $\begin{array}{l}\text { In CKD subjects, kidney } \\
\text { function did not improve by } \\
\text { reducing the SUA levels with } \\
\text { benzbromarone }\end{array}$ & Potentially hepatotoxic \\
\hline Losartan & $\begin{array}{l}\text { Unique angiotensin } \\
\text { receptor blocker which } \\
\text { blockade URAT 1 } \\
\text { (uricosuric) }\end{array}$ & $\begin{array}{l}\text { In posthoc analysis of REENAL, } \\
\text { the risk of doubling of SCr or } \\
\text { development of CKD 5 was } \\
\text { decreased by 6\% for every 0,5 } \\
\text { mg/dL decrement in SUA }\end{array}$ & $\begin{array}{l}\text { Uricosuric effect of } \\
\text { losartan accounts for } \\
\text { approximately one-fifth } \\
\text { of its renoprotective } \\
\text { effects }\end{array}$ \\
\hline Acetylsalicylic acid & $\begin{array}{l}\text { High dosages (>3 gm/day) } \\
\text { are uricosuric, while low } \\
\text { dosages (75-325 mg/day) } \\
\text { cause SUA retention }\end{array}$ & $\begin{array}{l}\text { Increase SUA and rates of acute } \\
\text { gout flares in patients with } \\
\text { prevalent gout and cardiovascular } \\
\text { prophylaxis }\end{array}$ & $\begin{array}{l}\text { Discontinuation is } \\
\text { generally not required, } \\
\text { given the beneficial } \\
\text { effects on mortality }\end{array}$ \\
\hline
\end{tabular}


Continuation of Table 3

\begin{tabular}{|c|c|c|c|}
\hline Drug & Mechanism & Evidence & Comment \\
\hline SGLT2 inhibitors & Uricosuric & $\begin{array}{l}\text { In subjects with diabetes, reduce } \\
\text { SUA by } 18-54 \mu \mathrm{mol} / \mathrm{L}\end{array}$ & $\begin{array}{l}\text { Small SUA reductions } \\
\text { alone unlikely explain } \\
\text { the observed renal and } \\
\text { cardiovascular benefits }\end{array}$ \\
\hline Fenofibrate & Uricosuric & $\begin{array}{l}200 \mathrm{mg} / \text { day reduced a } 19 \% \text { in } \\
\text { SUA }\end{array}$ & \\
\hline Vitamin C & Uricosuric & $\begin{array}{l}\text { Supplementation with } 500 \mathrm{mg} / \\
\text { day of vitamin C for } 2 \text { months } \\
\text { reduces SUA }\end{array}$ & $\begin{array}{l}\text { May induce } \\
\text { hyperoxaluria }\end{array}$ \\
\hline
\end{tabular}

\begin{tabular}{|c|c|c|c|}
\hline Randomized & Name & & Comment \\
\hline CKD-FIX study [13] & $\begin{array}{l}\text { The Controlled trial } \\
\text { of slowing of kidney } \\
\text { disease progression } \\
\text { From the Inhibition of } \\
\text { Xanthine oxidase }\end{array}$ & $\begin{array}{l}\text { To assess the effect of } \\
\text { allopurinol on slowing the } \\
\text { decline of eGFR }\end{array}$ & $\begin{array}{l}620 \text { patients with stages } \\
\text { 3-4 CKD }\end{array}$ \\
\hline FEATHER [40] & $\begin{array}{l}\text { Febuxostat versus } \\
\text { placebo randomized } \\
\text { controlled trial } \\
\text { regarding reduced renal } \\
\text { function in patients } \\
\text { with hyperuricemia } \\
\text { complicated by CKD } \\
\text { stage } 3\end{array}$ & $\begin{array}{l}\text { To assess the effect of } \\
\text { allopurinol versus placebo on } \\
\text { slowing the decline of eGFR }\end{array}$ & $\begin{array}{l}400 \text { Japanese patients } \\
\text { aged } 20 \text { or older who } \\
\text { have hyperuricemia } \\
\text { without gouty arthritis, } \\
\text { who present with CKD } \\
\text { stage } 3 \text {, and whose SUA } \\
\text { concentration is } 422 \text { - } \\
595 \mu \mathrm{mol} / \mathrm{L}\end{array}$ \\
\hline The PERL [54] & $\begin{array}{l}\text { The preventing early } \\
\text { renal loss }\end{array}$ & $\begin{array}{l}\text { To assess the effect of } \\
\text { allopurinol (dose ranging } \\
200-400 \mathrm{mg} \text { ) or placebo on } \\
\text { the GFR following the } 3 \text {-year } \\
\text { treatment period, measured } \\
\text { by the plasma clearance of } \\
\text { non-radioactive iohexol } \\
\text { (iGFR) and adjusted for the } \\
\text { iGFR at baseline }\end{array}$ & $\begin{array}{l}\text { Clinical trial at } 8 \\
\text { diabetes centers, } \\
\text { enrolling approximately } \\
480 \text { patients with } \\
\text { type } 1 \text { diabetes who } \\
\text { are at increased risk } \\
\text { of developing kidney } \\
\text { disease }\end{array}$ \\
\hline \multirow[t]{2}{*}{ Other RCT } & $\begin{array}{l}\text { Febuxostat and } \\
\text { benzbromarone [41] }\end{array}$ & $\begin{array}{l}\text { To assess the effect } \\
\text { of febuxostat and } \\
\text { benzbromarone for changes } \\
\text { in proteinuria and eGFR }\end{array}$ & $\begin{array}{l}\text { CKD patients with GFR } \\
20-50 \mathrm{~mL} / \mathrm{min}\end{array}$ \\
\hline & $\begin{array}{l}\text { Verinurad and } \\
\text { febuxostat [43] }\end{array}$ & $\begin{array}{l}\text { To assess the potential clinical } \\
\text { benefits of the combination } \\
\text { of Verinurad, a novel Urate } \\
\text { Transporter } 1 \text { inhibitor, } \\
\text { and Febuxostat in lowering } \\
\text { concentrations of circulating } \\
\text { uric acid and thus improving } \\
\text { kidney or cardiovascular } \\
\text { status of }\end{array}$ & $\begin{array}{l}\text { Patients with } \\
\text { hyperuricemia, } \\
\text { albuminuria, and type } 2 \\
\text { diabetes }\end{array}$ \\
\hline $\begin{array}{l}\text { CKD, chronic } \\
\text { clinical trials }\end{array}$ & 1. & morfilution noto CUA & uric acid; RCT, randomized \\
\hline
\end{tabular}


There is serious experimental and epidemiological evidence as well as a number of clinical trials to support a relationship of HUA to CKD, and that UA lowering treatment might forestall CKD progression. These trials were of limited duration and included only small number of patients. Only large randomized controlled trials (RCTs) would provide definitive answers about efficacy and safety of a pharmacological treatment for asymptomatic HUA in CKD. The dangers of inappropriately treating asymptomatic HUA are well documented [59, 63, 64]. Large RCTs on treatment of HUA for primary or secondary CKD prophylaxis are under way in populations with hypertension or diabetic nephropathy. The unavailability of these RCTs - despite the serious evidence that UA lowering drugs could be suggested for asymptomatic HUA in the setting of CKD - makes a routine recommendation of these drugs unsubstantiated. Finally, in respect of HUA, only lifestyle and dietary modifications along with an appropriate treatment for gout and UA lithiasis are today the only recommended

\section{References:}

1. Chung W, Kim AJ, Ro H, Chang JH, Lee HH, Jung JY. HUA is an independent risk factor for mortality only if chronic kidney disease is present. Am J Nephrol. 2013;37(5):452-461. doi: 10.1159/000350534.

2. Trigka K, PatrasGreece KS, Fourtounas $C$. HUA and chronic kidney disease: an enigma yet to be solved. Renal failure. 2014;36(9):1351-1359. doi: 10.3109/ 0886022X.2014.947516

3. Bellomo G. UA and chronic kidney disease: A time to act? World J Nephrol. 2013;2(2):1725. doi: $10.5527 /$ wjn.v2.i2.17

4. Eleftheriadis $T$, Golphinopoulos $S$, Pissas $G$, Stefanidis I. Asymptomatic HUA and chronic kidney disease: Narrative review of a treatment controversial. Journal of Advanced Research. 2017 Sep; 8(5):555. doi: 10.1016/j.jare.2017.05.001

5. Madero M, Sarnak MJ, Wang X, Greene T, Beck GJ, Kusek $J W$. UA and long-term outcomes in CKD. Am J Kidney Dis. 2009;53:796-803. doi: 10.1053/ j.ajkd.2008.12.021

6. Prasad Sah OS, Qing YX. Associations Between HUA and Chronic Kidney Disease: A Review, Nephro-Urol Mon. 2015 ;7(3):e27233. doi: 10.5812/numonthly.7(3)2015.27233.

7. Singh JA. Racial and gender disparities among patients with gout. Curr Rheumatol Rep. 2013;15(2):307. doi: 10.1007/s11926-012-0307-X.

8. Bakan A, Oral A, Elcioglu OC, Takir M, Kostek O, Ozkok A. HUA is associated with progression of IgA nephropathy. Int Urol Nephrol. 2015;47:673-678. doi: 10.1007/s11255-015-0939-7
Conclusions. An elevated UA is strongly associated with the development of CKD, but not ubiquitously with the progression of CKD. The real significance of this old molecule is widely discussed but at this moment remains obscure whether UA is cause of CKD, compensation mechanism, coincidence, consequence of CKD or concurrent phenomenon.

It could be assumed that HUA is an indirect cause of kidney disease, but the difficulty to clarify the role of UA as an independent risk factor for CKD is mainly due to the complex correlations and interactions between UA and conventional risk factors for CKD; the clarification of the relationship between UA and CKD progression remains an evolving area of research.

Treatment of HUA may be considered as an option for slowing progression of renal disease especially in the loop of the simple treatment such as use of a single antyuric acid agent as well as lifestyle changes.

More prospective randomized and well-designed trials with a large number of participants are needed to clarify the exact relationship among UA, development \& progression of CKD and CV mortality.

9. Jalal DI, Rivard CJ, Johnson RJ, et al. Serum UA levels predict the development of albuminuria over 6 years in patients with type 1 diabetes: Findings from the coronary artery calcification in type 1 diabetes study. Nephrol Dial Transplant. 2010;25(6):18651869. doi: $10.1093 / \mathrm{ndt} / \mathrm{gfp} 740$

10. Johnson RJ, Nakagawa T, Jalal D, SnchezLozada LG, Kang DH, Ritz E. UA and chronic kidney disease: Which is chasing which? Nephrol Dial Transplant. 2013;28(9):2221-2228. doi: 10.1093/ ndt/gft029

11. Kim WJ, Kim SS, Bae MJ, et al. High-normal serum UA predicts the development of chronic kidney disease in patients with type 2 diabetes mellitus and preserved kidney function. $\mathrm{J}$ Diabetes Complications. 2014;28(2):130-134. doi: 10.1016/j.jdiacomp.2013.11.006

12. Koratala A, Singhania $G$, Alquadan $K F$, Shimada $M$, Johnson RJ, Ejaz AA. Serum UA Exhibits Inverse Relationship with Estimated Glomerular Filtration Rate. Nephron. 2016;134:231-237. doi: 10.1159/000448629.

13. Mende $C$. Management of chronic kidney disease: the relationship between serum UA and development of nephropathy. Adv Ther. 2015;32:11771191. doi: 10.1007/s12325-015-0272-7.

14. Shi $Y$, Chen $W$, Jalal D, Li Z, Chen $W$, Mao $H$. Clinical outcome of HUA in IgA nephropathy: a retrospective cohort study and randomized controlled trial. Kidney Blood Press Res. 2012;35:153160. doi: 10.1159/000331453

15. Trevi o-Becerra A, Iseki $K$ (eds). UA in Chronic Kidney Disease. Contrib Nephrol. Basel, Karger. 2018;192:135-146. doi: 10.1159/000484279. 
16. Tsai $C W$, Lin $S Y$, Kuo CC, Huang CC. Serum UA and Progression of Kidney Disease: A Longitudinal Analysis and Mini-Review. PLoS ONE. 2017;12(1): e0170393. doi: 10.1371/journal.pone.0170393.

17. Zoppini G, Targher G, Chonchol M, et al. Serum UA levels and incident chronic kidney disease in patients with type 2 diabetes and preserved kidney function. Diabetes Care. 2012;35(1):99-104. doi: 10.2337/dc11-1346.

18. Wang $Y$, Bao X. Effects of UA on endothelial dysfunction in early chronic kidney disease and its mechanisms. Eur J Med Res. 2013;18(1):26. 4. doi: 10.1186/2047-783X-18-26

19. Kohagura K, Kochi M, Miyagi T, Kinjyo $T$, Maehara $Y$, Nagahama K. An association between UA levels and renal arteriolopathy in chronic kidney disease: a biopsy-based study. Hypertens Res. 2013;36:43-49. 4. doi: 10.1038/hr.2012.135

20. Whelton A, Macdonald PA, Zhao L, Hunt B, Gunawardhana $L$. Renal function in gout: long term treatment effects of Febuxostat. J Clin Rheumatol. 2011;17(1):7-13. doi: 10.1097/ RHU.0b013e318204aab4.

21. Chuengsamarn S, Rattanamongkolgul S, Jirawatnotai $S$. Association between serum UA level and microalbuminuria to chronic vascular complications in Thai patients with type 2 diabetes. J Diabetes Complications. 2014;28(2):124129. doi: 10.1016/j.jdiacomp.2013.12.002

22. Zhang Y, Yamamoto T, Hisatome I, et al. UA induces oxidative stress and growth inhibition by activating adenosine monophosphate-activated protein kinase and extracellular signal-regulated kinase signal pathways in pancreatic cells. Mol Cell Endocrinol. 2013;375(1-2):89-96. doi: 10.1016/j. mce.2013.04.027.

23. Dogan A, Yarlioglues $M$, Kaya $M G$, et al. Effect of long-term and high-dose allopurinol therapy on endothelial function in normotensive diabetic patients. Blood Press. 2011;20(3):182-187. doi: 10.3109/08037051.2010.538977.

24. Puddu P, Puddu GM, Cravero E, Vizioli L, Muscari A. Relationships among HUA, endothelial dysfunction and cardiovascular disease: Molecular mechanisms and clinical implications. J Cardiol. 2012;59(3):235-242 . doi: 10.1016/j. jjcc.2012.01.013.

25. Kanellis J, Kang DH. UA as a mediator of endothelial dysfunction, inflammation, and vascular disease. Semin Nephrol. 2005;25(1):39-42 doi: 10.1016/j.semnephrol.2004.09.007

26. Boban M, Kocic G, Radenkovic S, et al. Circulating purine compounds, UA, and $\mathrm{XO} /$ dehydrogenase relationship in essential hypertension and end stage renal disease. Ren Fail. 2014;36(4):613-618. doi: 10.3109/0886022X.2014.882240
27. Ling $Y$, Li XM, Gao $X$. Cross-sectional association of serum C-reactive protein and UA with albuminuria in Chinese type 2 diabetic patients. Chin Med J (Engl). 2013;126(21):4023-4029. doi: 10.3760/ cma.j.issn.0366-6999.20131485

28. Terawaki H, Nakayama M, Miyazawa E, et al. Effect of allopurinol on cardiovascular incidence among hypertensive nephropathy patients: The Gonryo study. Clin Exp Nephrol. 2013;17(4):549-553. doi: 10.1007/s10157-012-0742-z.

29. Yoshimura A, Adachi H, Hirai $Y$, et al. Serum UA is associated with the left ventricular mass index in males of a general population. Int Heart J. 2014;55(1):65-70. doi: 10.1536/ihj.13-170

30. Jalal DI, Chonchol M, Chen W, Targher G. UA as a target of therapy in CKD. Am J Kidney Dis. 2013;61(1):134-146. doi: 10.1016/j. jare.2017.04.007

31. Li L, Yang C, Zhao $Y$, Zeng $X$, Liu F, Fu P. Is HUA an independent risk factor for new-onset chronic kidney disease? A systematic review and metaanalysis based on observational cohort studies. BMC Nephrol. 2014;15:122. doi: 10.1186/14712369-15-122.

32. Uchida S, Chang WX, Ota T, Tamura $Y$, Shiraishi $T$, Kumagai $T$. Targeting UA and the inhibition of progression to end-stage renal disease-a propensity score analysis. PLoS One. 2015;10:e0145506. doi: 10.1371/journal.pone.0145506

33. Sturm $G$, Kollerits B, Neyer U, Ritz E, Kronenberg F. MMKD Study Group. UA as a risk factor for progression of non-diabetic chronic kidney disease? The Mild to Moderate Kidney Disease (MMKD) Study. Exp Gerontol. 2008;43(4):347-352. doi: 10.1016/j.exger.2008.01.006

34. Goicoechea M, Garcia $d V$., Verdalles $U$, Verde E, Macias $N$, Santos A. Allopurinol and progression of CKD and cardiovascular events: long-term followup of a randomized clinical trial. Am J Kidney Dis. 2015;65:543-549. doi: 10.1053/j.ajkd.2014.11.016

35. Ramirez MEG., Bargman J.M. Treatment of asymptomatic HUA in chronic kidney disease: A new target in an old enemy - A review. J Adv Res. 2017 Sep; 8(5): 551-554. doi: 10.1016/j.jare.2017.04.006

36. Waring WS, McKnight JA, Webb DJ, Maxwell SR. Lowering serum urate does not improve endothelial function in patients with type 2 diabetes. Diabetologia. 2007;50(12):2572-2579. doi:10.1007/s00125-007-0817-7

37. Sowers JR. Diabetes mellitus and vascular disease. Hypertension. 2013;61(5):943-947. doi: 10.1161/ HYPERTENSIONAHA.111.00612 .

38. Altemtam N, Russell J, El Nahas M. A study of the natural history of diabetic kidney disease. (DKD) Nephrol Dial Transplant. 2012;27:1847-1854. doi: 10.1093/ndt/gfr561. 
39. Ito $H$, Abe $M$, Mifune $M$, et al. HUA is independently associated with coronary heart disease and renal dysfunction in patients with type 2 diabetes mellitus. PLoS One. 2011;6(11):e27817. doi: 10.1371/ journal.pone.0027817.

40. Miao $Y$, Ottenbros $S A$, Laverman $G D$, et al. Effect of a reduction in UA on renal outcomes during losartan treatment: A post hoc analysis of the reduction of endpoints in non-insulin-dependent diabetes mellitus with the Angiotensin II Antagonist Losartan Trial. Hypertension. 2011;58(1):2-7. doi: 10.1161/HYPERTENSIONAHA.111.171488.

41. Nitta $K$, Iimuro $S$, Imai $E$, et al. Risk factors for increased left ventricular hypertrophy in patients with chronic kidney disease. Clin Exp Nephrol. 2013;17(5):730742. doi: 10.1007/s10157-012-0758-4.

42. Sheikhbahaei S, Fotouhi A, Hafezi-Nejad $N$, Nakhjavani $M$, Esteghamati A. Serum UA, the metabolic syndrome, and the risk of chronic kidney disease in patients with type 2 diabetes. Metab Syndr Relat Disord. 2014;12(2):102-109. doi: 10.2215/ CJN.03140315

43. Pai BH, Swarnalatha $G$, Ram R, Dakshinamurty $K V$. Allopurinol for prevention of progression of kidney disease with HUA. IndianJ Nephrol. 2013;23(4):280286. doi: 10.4103/0971-4065.114499

44. Sedaghat S, Hoorn EJ, van Rooij FJ, et al. Serum UA and chronic kidney disease: The role of hypertension. PLoS One. 2013;8(11):e76827. doi: 10.1371/ journal.pone.0076827

45. Sezai A, Soma M, Nakata K, etal. Comparison offebuxostat and allopurinol for HUA in cardiac surgery patients (NU-FLASH Trial). Circ J. 2013;77(8):20432049. doi:10.1253/circj.CJ-13-0082

46. Gois PH, Souza ER. Pharmacotherapy for HUA in hypertensive patients. Cochrane Database Syst Rev. 2013;1:CD008652. doi: 10.1002/14651858.

47. Sezer S, Karakan S, Atesagaoglu B, Acar FN. Allopurinol reduces cardiovascular risks and improves renal function in pre-dialysis chronic kidney disease patients with HUA. Saudi J Kidney Dis Transpl. 2014;25(2):316-320. doi: 10.4103/13192442.128520

48. Gibson $T$, Rodgers $V$, Potter $C$, HA Simmonds. Allopurinol treatment and its effect on renal function in gout: a controlled study. Ann Rheum Dise. 1982;41(1):59-65. doi: 10.1136/ard.41.1.59

49. Chanard J, Toupance O, Lavaud S, Hurault de Ligny B, Bernaud C, Moulin B. Amlodipine reduces cyclosporine-induced HUA in hypertensive renal transplant recipients. Nephrol Dial Transplant. 2003;18(10):2147-2153. doi:10.1093/ndt/gfg341

50. Siu YP, Leung KT, Tong MK, Kwan TH. Use of allopurinol in slowing the progression of renal disease through its ability to lower serum UA level. Am J Kidney Dis. 2006;47:51-59. doi: 10.1053/j. ajkd.2005.10.006
51. Liu WC, Hung CC, Chen SC, et al. Association of HUA with renal outcomes, cardiovascular disease, and mortality. Clin J Am Soc Nephrol. 2012;7(4):541-548. doi: 10.2215/CJN.09420911

52. Kanbay M, Yilmaz MI, Sonmez A, et al. Serum UA independently predicts cardiovascular events in advanced nephropathy. Am J Nephrol. 2012;36(4):324-331. doi: 10.1159/000342390

53. Malaguarnera $M$, Vacante $M$, Russo $C$, Dipasquale $G$, Gargante MP, Motta M. A single dose of rasburicase in elderly patients with HUA reduces serum UA levels and improves renal function. Expert Opn Pharmacother. 2009;10(5):737-742. doi: $10.1517 / 14656560902781972$

54. Momeni A, Shahidi S, Seirafian S, Taheri $S$, Kheiri $S$. Effect of allopurinol in decreasing proteinuria in type 2 diabetic patients. Iran J Kidney Dis. 2010;4(2):128-132. http://www.ijkd.org/index.php/ijkd/article/view/200/183

55. Sircar D, Chatterjee S, Waikhom $R$, Golay $V$, Raychaudhury A, Chatterjee S. Efficacy of febuxostat for slowing the GFR decline in patients with CKD and asymptomatic HUA: a 6-month, doubleblind, randomized, placebo-controlled trial. Am J Kidney Dis. 2015;66:945-950. doi: 10.1053/j. ajkd.2015.05.017

56. Dong J, Han QF, Zhu TY, et al. The associations of UA, cardiovascular and all-cause mortality in peritoneal dialysispatients. PLoS One. 2014;9(1):e82342. doi: 10.1371/journal.pone.0082342

57. Wang $H$, Wei $Y$, Kong $X, X u$ D. Effects of uratelowering therapy in HUA on slowing the progression of renal function: A meta-analysis. J Ren Nutr. 2013;23(5):389-396. doi: 10.1053/j. jrn.2012.08.005.

58. Sakai Y, Otsuka T, Ohno D, Murasawa T, Sato N, Tsuruoka $S$. Febuxostat for treating allopurinol-resistant HUA in patients with chronic kidney disease. Ren Fail. 2014;36(2):225-231. doi: 10.3109/0886022X.2013.844622

59. Pasina L, Brucato AL, Djade CD, Di Corato P, Ghidoni $S$, Tettamanti $M$. Inappropriate prescription of allopurinol and febuxostat and risk of adverse events in the elderly: results from the REPOSI registry. Eur J Clin Pharmacol. 2014;70:1495-1503. doi: 10.1007/s00228-014-1752-4

60. Feng $S$, Jiang $L$, Shi $Y$, et al. UA levels and all-cause mortality in peritoneal dialysis patients. Kidney Blood Press Res. 2013;37(2-3):181-189. doi: 10.1159/000350143

61. Kanji T., Gandhi M., Clase C.M., Yang R. Urate lowering therapy to improve renal outcomes in patients with chronic kidney disease: systematic review and meta-analysis. BMC Nephrol. 2015;16:58. doi: 10.1186/s12882-015-0047-z. 
62. Bose B, Badve SV, Hiremath SS, et al. Effects of UA-lowering therapy on renal outcomes: A systematic review and meta-analysis. Nephrol Dial Transplant. 2014;29(2):406-413. doi: 10.1093/ ndt/gft 378

63. Hosoya T, Ohno I, Nomura S, Hisatome I, Uchida S, Fujimori $S$. Effects of topiroxostat on the serum urate levels and urinary albumin excretion in hyperuricemic stage 3 chronic kidney disease patients with or without gout. Clin Exp Nephrol. 2014;18:876-884. doi: 10.1007/s10157-014-0935-8

64. Hosoya $T$, Kimura $K$, Itoh $S$, Inaba $M$, Uchida $S$, Tomino $Y$. The effect of febuxostat to prevent a further reduction in renal function of patients with HUA who have never had gout and are complicated by chronic kidney disease stage 3 : study protocol for a multicenter randomized controlled study. Trials. 2014;15:26. doi: 10.1186/1745-6215-15-26

65. Davies MJ., Trujillo A, Vijapurkar U, Damaraju CV, Meininger $G$. Effect of canagliflozin on serum UA in patients with type 2 diabetes mellitus. Diabetes Obes Metab. 2015;17:426-429. doi: 10.1111/ dom.12439

66. Wanner $C$, Inzucchi SE, Lachin JM, Fitchett D, von Eynatten $M$, Mattheus $M$. Empagliflozin and progression of kidney disease in type 2 diabetes. N Engl J Med 2016;375:323-334. doi: 10.1056/ NEJMc1611290.

67. Cheung AK, Sarnak MJ, Yan G, et al. Cardiac diseases in maintenance hemodialysis patients: Results of the HEMO Study. Kidney Int. 2004;65(6):2380-2389. doi:10.1111/j.15231755.2004.00657.x

68. Lee CT, Chua S, Hsu CY, et al. Biomarkers associated with vascular and valvular calcification in chronic hemodialysis patients. Dis Markers. 2013;34(4):229-235. doi: 10.3233/DMA-130965

69. Antunovic $T$, Stefanovic A, Ratkovic $M$, et al. High UA and low superoxide dismutase as possible predictors of all-cause and cardiovascular mortality in hemodialysis patients. Int Urol Nephrol. 2013;45(4):1111-1119 doi: 10.1681/ ASN.2018010086

70. Lobo JC, Stockler-Pinto MB, da Nbrega AC, Carraro-Eduardo JC, Mafra $D$. Is there association between UA and inflammation in hemodialysis patients? Ren Fail. 2013;35(3):361-366. doi: 10.3109/0886022X.2013.764274

71. Latif $W$, Karaboyas A, Tong L, et al. UA levels and all-cause and cardiovascular mortality in the hemodialysis population. Clin J Am Soc Nephrol. 2011;6(10):2470-2477. doi: 10.2215/ CJN.00670111

72. Xia X, He F, Wu X, Peng F, Huang $F, Y u X$. Relationship between serum UA and allcause and cardiovascular mortality in patients treated with peritoneal dialysis. Am J Kidney Dis. 2014;64(2):257-264. doi: 10.1053/ j.ajkd.2013.08.027 